\title{
Land Rights Disputes Between Landowners And Mining Companies : A Case Study In Banyuwangi Regency, East Java, Indonesia
}

\author{
Iwan Permadi \\ Faculty of Law \\ Brawijaya University \\ Malang, Indonesia \\ iwan_permadi@ub.ac.id
}

\author{
Reka Dewantara \\ Faculty of Law \\ Brawijaya University \\ Malang, Indonesia \\ rainerfh@ub.ac.id
}

\begin{abstract}
This article explores an issue where the mining company as the owner of the right to mining remains unable to directly extract mining products from within the land or mine without the consent of the landowner or the holder of the land rights despite the fact that the mining company holds a Mining Business License granted by the government. The mining company must first settle the rights to the land with its owner even though the company has obtained permission from the government to conduct mining business activities. The research methodology was an integration of empirical juridical research methods and interpretation of the normative method results. The results indicated that with the settlement of land rights between mining companies and holders of land rights in accordance with the provisions of the Indonesia Mining Act, it is hoped that no party will feel disadvantaged even the parties can gain benefit from the mining business. While it is clearly regulated on the obligations of mining companies to settle land rights as mining land, empirically, there are many miningrelated cases that are not in accordance with the regulations.
\end{abstract}

Keywords- disputes, landowner, company, mine, banyuwangi regency.

\section{INT RODUCTION}

Indonesia has some of the world's largest reserves of gold and other minerals, and commodity prices have soared in recent years. The price of gold has continuously risen from US\$384.40 in 1996 to US\$444.74 in 2005. Indonesia's resource potential is ranked above Zimbabwe, South Africa, Bolivia, Mongolia, Western Australia, Chile, Nevada, Russian and Congo. Yet the Wall Street Journal in February this year reported that mining companies "haven't broken ground on a single mine here since Asia's 1997-98 financial crisis" [1]. The poor condition in mining exploration is often experienced by wealthy developing countries. It is worsened by low production capability in manufacturing sector known as" Dutch Disease.". In this context it is important to view how Indonesia exploits its mining products of mineral and coal which did not rule out the possibility that leads to the worst condition [2].

The dispute between residents living in Banyuwangi Regency of East Java Province and mining activity in Tumpang Pitu area has been going on since 1997. Local residents rejected the mining operation because they were concerned about the impact given to Tumpang Pitu. Tumpang Pitu area is a mountainous area in Banyuwangi Regency. Mount Tumpang Pitu is believed by local residents as a protector from wind blowing from the southwest and protector against tsunami disaster. Based on an analysis from a non-governmental organization called Indonesian Forum of Environment (further stated as WALHI) of East Java, the release of Java's southern coastal area to the mining area will certainly trigger social conflict involving citizens because it is in direct contact with the land owned by the residents. In addition, the utilization of coastal areas for mining is not in accordance with national and provincial spatial plans. The area has been declared vulnerable to the ts unami disaster and is a productive area for the cultivation of agriculture as well as traditional fishing fisheries.

PT. BSI as a mining company obtained mining permit to conduct exploration in the area of Mount Pitu. The mining permit approval by PT. BSI is considered loaded with interests. The government's permit was issued too early, beginning with the change of status of Mount Tumpang Pitu from protected forest area into production forest. Forestry Minister Zulkifli Hasan then, on November 19, 2013, has changed the status of Tumpang Pitu Mountain as a Protected Forest to production forest through the Decree of Minister of Forestry Number SK 826 / Menhut-II/ 2013.

The forest covering 1,942 hectares was approved by the proposal of the Banyuwangi Regent Abdullah Azwar Anas through letter No. 522/635/429/108/2012 dated October 10, 2012 with an area of $9,743.28$ hectares or 5 times that approved by the Minister of Forestry. As an area prone to disaster, Mount Tumpang Pitu was hit by the Tsunami on June 3, 1994. Easily providing mining permit severely jeopardizes the safety of the people around Tumpang Pitu. Gold exploitation in Tumpang pitu will also threaten the life of people who depend on their lives as farmers and fishermen. Exploration activities using thousands of trucks dredging will certainly affect the agricultural output of the community in Tumpang Pitu because the function of forest as an area of absorption or storage of water resources will be significantly disrupted. Pollution from waste that is disposed of directly into the sea will harm the life of fishermen who are very dependent on fish catches. Moreover, the potential of mining in coastal areas of East Java contain many minerals. Water is an important and main element of a gold 
refining process carried out by mining companies, including in Tumpang Pitu. The water need ass essment conducted by Mining Advocacy Network (Jatam) in 2008 mentions that the process of gold purification requires water in very large quantities. It is estimated that the gold mining activity in Tumpang Pitu consumes 2,038 million liters of water every day in Banyuwangi Regency.

Information and data needed to support the results of the study were obtained to analyze how disputes over land rights occurred between mining companies and landowners regarding the land situated for mining company. The research methodology comprised the integration of juridical empirical research methods and interpretation of the legal material.

The sociological juridical approach is used to determine the validity of the norms in society.

\section{DISCUSSION}

\section{A. Juridical Analysis Of The Legal Status of Dispute Between The Land Owners And Mining Company In Banyuwangi Regency.}

The authority to manage and cultivate all natural resources in Indonesia including mine products is in the hands of the central government. However, in reality mining life can not be separated from corporate aspects because mining activities, in principle, aims to be utilized by the community in meeting their needs. In the United States, land generally can be categorised into surface and subsurface estates, creating a split estate where the surface and mineral rights can be held by different parties. The ability to sever the unified estate depends on land ownership [2]. In this case, mining companies have a role as an arm of the government in processing and managing mining products. In mining management, the authority granted by the government to a mining company is done by granting a Mining Business License (IUP). To perform mining activities, holding IUP for a company must also be strengthened by the approval of right to land holder in which the mining site sits on the land. Therefore, the mining company must immediately settle ownership of land rights with previous rights holder, as regulated in Article 135 and Article 136 of Act Number 4 Year 2009 regarding Mineral and Coal Mining.

In its development, as long as the agreement between PT BSI as the first party with the owner of the land as the second party takes place, there is a third party in this case called speculators, entering to conduct mining activities on the land. The second party tends to prefer to cooperate with speculators even if the mining activities conducted by these speculators are not in accordance with the applicable mining regulations, as they do not have IUP and also have not settled land rights with the landowners legally, because this third party has promised to the landowners that they will benefit more. Mining activities conducted by the third party or speculators is actually detrimental to PT BSI. The problem then raises a dispute between the first party that is PT BSI with the second party that is the land owner associated with the land lease agreement and profit sharing that has been agreed by both parties, because in this case the second party has injured the agreement or in other words has breached the contract against the first party, where the second party has violated the provisions of Article 1234 of the Civil Code [3].
While breach of contract is defined as a negligence where responsibility is not performed by the speculators; illegal mining is still performed without Mining Business License (IUP) at the area that belongs to another mining company which holds IUP or principles as set in the agreement between a creditor and a debtor. The new law simplifies mining administration by eliminating distinctions between foreign and domestic investors. Under the new law, both domestic and foreign investors will operate mines under the authority of a "mining operation permit" (Izin Usaha Pertambangan, IUP) or a "mining operation agreement" (Perjanjian Usaha Pertambangan, PUP). For s mall-scale traditional miners, a "people's mining license" (IPR) will be issued. Under the CoW system, domestic investors could perform mining operation under a delegated mining right (Kuasa Pertambangan or KP), a local mining permit (Surat Izin Pertambangan Daerah, SIPD) and foreign investors operated under the special terms of the CoW (Kontrak Karya, KK) [4]. Thus under the provisions of Article 1234 of the Civil Code, it is clear that the second party has defaulted against the first party, because in the agreement made between PT BSI and the landowner it is stipulated that the land owner as a second party is prohibited to rent or grant the land or allow other parties to use and utilize the land which is the object of the agreement, whether for mining activities or other matters as long as the agreement is not over.

Mining business activities carried out by PT BSI include exploration and exploitation of mining materials, as defined in the mining that has been described previously. Exploration in this case is: "The stages of mining business activities to obtain detailed and accurate information about the location, shape, dimensions, distribution, quality and measurable resources of excavated materials, as well as information on the society and environment." exploitation or in the Mining Act referred to as production operations are: "Stages of mining business activities include construction, mining, refining, including transportation and sales, as well as means of controlling environmental impacts in accordance with the results of a feasibility study."

To be able to perform mining activities, in addition to requiring IUP, PT BSI also requires permission or approval from the land owner. This is because on the land or land to be mined is still attached to the land right of the owner. Reclamation is an activity undertaken throughout the mining business to organize, restore and improve the quality of the environment and ecosystem in order to revive the land in accordance with its allocation (Act No. 4 of 2009 regarding Mineral and Coal Mining). The landowner is entitled to receive compensation if $h$ is land is used as a mine by PT BSI. Reimbursement means the obligation of a mining company, PT BSI, to settle or exempt land rights from landholders as holders of land rights. This is basically also regulated in the Mining Act, namely in Article 135 and Article 136. Regulations concerning the obligations of mining companies to settle the ownership of land rights with landholders in the Mining Act are further described in Article 100 paragraphs (1) and (2) Government Regulation (PP) No. 23/2010 concerning Implementation of Mineral and Coal Mining Business Activities. The settlement of ownership of land rights and compensation as referred to in Government Regulation Number 23 of 2010 above can be in the form of leases, trading, and borrowing, while the settlement or disposal of land rights by PT BSI to the land owner as the holder of land rights in Tumpang Pitu is performed by 
making land lease agreements with the land owner. With the lease agreement, PT BSI gets permis sion to mine on the land in question, and the landowner receives compensation of amount of money in accordance with the price agreed by both parties in the lease agreement.

The mining business of PT BSI located in Tumpang Pitu Banyuwangi Regency has obtained Mining Business License (IUP) from Local Government of Banyuwangi in this case Banyuwangi Regent. In addition, PT BSI is also involved in an agreement with the mining site land owner for further exploration and exploitation activities. This is done by PT BSI as regulated in the Mining Act implying that prior to mining activities, PT BSI as a mining company must have IUP and must first settle land rights with the holder of land rights to allow mining activities on the site. The agreement made is a land lease agreement. Initially, the agreement and agreements that were made jointly between PT BSI and the landowners were well received and all agreements went according to what had been agreed between the parties concerned. However, some irregularities were found in lease agreements agreed by both sides. Along with rapid mining activities that exist in the Mining Business License (WIUP) of PT BSI, illegal miners commonly called speculators as third parties, both from domestic and outside the country, began to dis rupt mining activities of PT BSI, by offerring colaboration with landowners living near the mine is the land. The arrival of these illegal miners can not be held back by PT BSI. Furthermore, these illegal miners or speculators work with capital providers to obtain iron sand mining land directly from the landowners, although in reality the mine land is located in the PT BSI WIUP.

Since the entry of a third party of illegal miners or speculators, landowners as second parties tend to prefer to cooperate with speculators. Second-party considerations in the tendency to cooperate with these speculators are limited only because they want more profit. The illegal miners of course provide a better profit offer and promise that it will provide more facilities in comparis on to the benefits received by both parties from PT BSI. A lthough the mining activities conducted by these speculators are not in accordance with the applicable mining regulations, since the third party or speculators does not have a Mining Business License (IUP) from the Local Government, the second party or landowner still chooses to cooperate with the speculator. Mining activities conducted the speculators as the third party are actually detrimental to PT BSI, mining activities of PT BSI are disrupted because the land was taken over by the illegal miners.

In this case the second party has harmed the agreement or in other words has violated the first party, where the second party has violated the content of the agreement, as regulated in Article 1234 of the Civil Code which reads "Every engagement is to give something, to do something, or not to do something". Whereas default is defined as: failing to fulfill or not fulfill the obligation or achievement as specified in the agreement made between the two parties, namely creditors and debtors. Based on the provisions of Article 1234 of the Civil Code, it is clear that the second party has violated the first party, because in the agreement made between PT BSI and the landowner, it was agreed that the landowner as the second party is prohibited from renting or giving away the land or allowing other parties to use and utilize the land that is the object of the agreement, either for illegal stockfile through illegal mining storage and washing or other aspects as long as the agreement is not over. Comparing with the regulation at Article 8 (civil- and familyrelated rights) of the First Protocol to the ECHR (rights to utilize property) has been interpreted to impose a duty on States to warn the public of the dangers to health and safety from dangerous facilities, including mining product washing, obligation to assure the health of the local community who is directly or indirectly exposed to the impacts of environmental exploration including mining which is prone to danger, and obligation to provide appropriate legal system and to take appropriate and effective action to prevent imminent threats from serious pollution to the health and safety of pers ons in their territories [4].

\section{B. Dispute Settlement of land ownership rights between a Mining Company and land owners in Banyuwangi Regency.}

The occurrence of conflicts and riots involving residents in the Tumpang Pitu, Banyuwangi regency, East Java, can not be separated from the problems of community life that depends on natural resources. The conflict triggered by gold mining permit granting in Tumpang Pitu by the Government of Banyuwangi Regency to the company, raises concerns about the loss of the livelihoods of people dependent on forests, mountains, beaches and coastal environments. Transferring the function of protected forests into mine has in fact triggered social conflicts, and this is a big disadvantage people face when operations are continuously underway (BAFFEL). Disputes between police officers and a number of residents of Pancer Hamlet, Sumberagung Village, Pesanggaran District triggered the rejection of residents against gold mining activities of PT. Bumi Suksesindo (BSI) in Gunung Tumpang Pitu area.

The conversion of the function of forests from protected areas to production has caused horizontal conflicts, threatening the survival of the community and the surrounding environment. In addition to horizontal conflicts, the operation of the gold mining in Tumpang Pitu also threatens animal life and the ecosystem. The results of an inventory of Environmental Impact Assessment have reported sea eagles and leopards live around the Tumpang Pitu mountains. If exploitation continues, it is feared to trigger the migration of wildlife from the region. Gold mining will certain ly affect ecosystems and the environment because chemicals such as mercury or cyanide used can damage the environment. If there is waste disposal, it is certain that animals in the coastal ecosystem are also threatened.

The problem is, an environmental impact analysis document says, every day the company needs 2.04 million liters of water to separate gold ores. The need will be extracted from Kalibaru River and Gonggo. The Kalibaru River and Setail have been irrigating rice fields in six subdistricts around Mount Tumpang Pitu. IMN's mining waste also has the potential to seep into the sea. The process of purifying gold from other metals requires cyanide. The IMN Environ mental Impact Analys is (amdal) report states that the company will dispose of 2,361 tons of tailings per day to Teluk Pancer in the west of Tumpang Pitu. Fishermen and fishery industries in southern Banyuwangi will cease to work and operate when chemicals pollute the sea. In fact, during this time, fish catches of five ports on the coast 
adjacent to Tumpang Pitu, namely Muncar, Pancer, Grajagan, Blimbingsari, and Wongsorejo, account for more than 50 thousand tons a year.

Local knowledge developed in the community should be the basis for policy making related to natural resource governance. Local knowledge is well known and has become the thinking process of decision-makers, but has not been used as formal knowledge. Thus, most policies adopted based on formal knowledge references are still minimu m [5]. Related to the mining conflict in Tu mpang Pitu, residents are still demanding information disclosure related to the mining operation plan near their residence. Non-litigation dispute settlement becomes very important, with openness and mutual trust. Limited community knowledge related to exploration and exploitation of natural resources is often ignored by policy makers before decisions are made. Limited public knowledge about mining will be very harmful to the community itself if the government inappropriately takes measures. This should be the government's knowledge before establishing a policy that has a major impact on life.

According to the Banyuwangi Trade and Mining Industry Office, the exploration of the gold mine in Tumpang Pitu is still on the right path. Requirements have been fulfilled in accordance with applicable regulations, involving administrative, technical, environmental and financial factors. The latest condition of Tumpang Pitu is based on the utilization permit of forest area obtained by the company. For concession areas for the use of borrowing permits, there are 194 hectares of approximately 900 hectares of production operations, while the location to be mined is within the mining permit area. The area may be opened or used for mining activities if outside the area is not allowed.

Economic reforms in Indonesia especially in mining exploration regulation needed to reforming its economic system. Regulation amendment purpose are to seek welfare rules to ensure economic justice through increased equitable distribution of development outcomes according to the concept of social economy [7]. To resolve the dispute that occurred in Tumpang Pitu, many efforts have been made by PT BSI. The in itial effort by PT BSI was to report the dispute to the Police, both at the Sector Police and East Java Police levels. However, the efforts of PT BSI did not bring results, where the Police did not respond to the report and suggested PT BSI to reconcile with the community and obey the wishes of the people in Tumpang Pitu. Reporting efforts conducted by PT BSI is increasingly triggering the temper of the locals and has caused the community to take repressive action. Moreover, the illegal miners or speculators actually stimulate communities around the mining area to refuse and stop mining activities done PT BSI on the grounds, and PT BSI is not willing to stop the mining activity in the region as promised. The problem encountered by PT BSI is very detrimental to its side recalling that the mining activities performed PT BSI have to stop long enough and the factory can not operate. Therefore, PT BSI tries other efforts to resolve the dispute. Further efforts undertaken by PT BSI is by means of peace-making through mediation with landowners and speculators as the third party. By way of mediation, it is hoped that no party will feel disadvantaged. From the mediation, it was agreed that the dispute between the parties namely PT BSI and the land owner is settled by win-win solution, which is mutually beneficial for both parties [8]. Therefore, PT BSI entered into a profit-sharing agreement with a second party, the landowner of PT BSI's mining activities. Local Governments also Establish Identification and Inventory Team on land that becomes the object of conflict. The team aims to find data on ownership status and calculate the value of growing plants and buildings located on the land. The Government of Banyuwangi Regency based on the regent's regulation has determined the amount of compensation and which parties are eligible to receive the compensation although the mining exploration will continue.

\section{REFERENCES}

[1] B. Bhasin and S. Venkataramany, "Mining Law and Policy: Replacing the 'Contract of Work' System in Indonesia", World Bank, Indonesia Policy Briefs, World Bank Ideas for the Future, January 2005, pp.2-5.

[2] D. Rahadian, Indonesia New Mining Law Regime: Balancing between State's and the Investor's Interest, Master's Thesis Tilburg University, unpublished, 2012, pp. 6-7.

[3] HS. Salim, Pengantar Hukum Perdata Tertulis (BW), Sinar Grafika, Jakarta, 2011. (references)

[4] E. Richer, "The Mining Law Review", Law Business Research Ltd, London 87 Lancaster Road, London, W11 1QQ, UK, 2016, pp. 236. (references)

[5] The British Council. Fuad, F.H. \& S. Maskanah.. Inovasi Penyelesaian Sengketa Pengelolaan Sumberdaya Hutan.. Bogor ; Pustaka LATIN, 2000.

[6] Y. Scannell The Regulation of Mining and Mining Waste in the European Union 3 Wash. \& Lee J. Energy, Climate, \& Env't 177, 2012,pp. 266-268

[7] R. Dewantara. Rekonseptualisasi Asas Demokrasi Ekonomi Dalam Konst it usi Indonesia. Arena Hukum, [S.1.], v. 7, n. 2, p. 195-209, june 2015. ISSN 2527-4406. Available at: <http://arenahukum.ub.ac.id/index.php/arena/article/view/157/156>. Date accessed: $10 \quad$ aug. 2018 doi:http://dx.doi.org/10.21776/ub.arenahukum.2014.00702.3.

[8] HS, Salim., Hukum Penyelesaian Sengketa Pertambangan Di Indonesia, Bandung; Pustaka Rineka Cipta. 2013. 